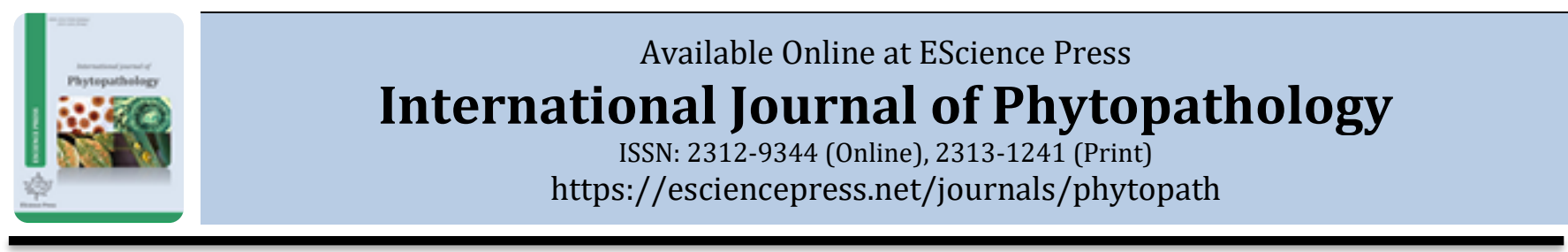

\title{
BIO-CONTROL OF THE LESION NEMATODE PRATYLENCHUS COFFEAE USING LIXIVIATE FROM BANANA RACHIS (MUSA SP.)
}

a,bSeri S. Pacome*, bGnonhouri Phillipe, aAssiri K. Patrice, cLouise Turquin, bSerge V. O. Theodore, aSéka Koutoua, a'Hortense A. Diallo

a Pôle de Recherche Production Végétale, Unité Santé des Plantes, Université Nangui Abrogoua, Abidjan 02, Côte d'Ivoire.

${ }^{b}$ Centre National de Recherche Agronomique, Laboratoire de nématologie, 01 BP 1536 Abidjan 01, Côte d'Ivoire.

${ }^{c}$ Laboratoire de physiologie végétale, UFR Biosciences, Université Félix Houphouët Boigny, Abidjan 22, Côte d'Ivoire.

*Corresponding Author Email: serserpaco@gmail.com

\section{A B S T R A C T}

The efficiency of lixiviate on the tolerance of plantain to root attacks of Pratylenchus coffeae has been examined. During the growing phase which lasted a month, four different treatments were applied to Banana plants of cultivars CORNE 1 and PITA 3: lix- (no lixiviate), lix100 (100\% lixiviate), lix25 (25\% lixiviate) and lix5 (5\% lixiviate). Then, these plants were inoculated with 500 individuals of $P$. coffeae to assess the effect of lixiviate treatments against nematodes on both cultivars CORNE 1 and PITA 3. This study showed that 5\% lixiviate and 25\% lixiviate doses gave better agronomic parameters (mass of root system, the collar circumference, pseudo stem height, leaf area and a number of leaves) evaluated on vivoplants. Cultivars CORNE 1 treated with 25\% lixiviate dose and cultivars PITA 3 treated with 5\% lixiviate dose, gained tolerance against nematode's attacks. Otherwise, cultivars PITA 3 were resistant to nematodes after $25 \%$ lixiviate dosage because $P$. coffeae were reduced by $80 \%$ in this treatment. The results presented in this work are encouraging for the development of biological control methods of banana nematodes by lixiviate.

Keywords: Plantain, lixiviate, nematode, agronomic parameters, resistance, tolerance

\section{INTRODUCTION}

Among the main banana pests, nematodes (alone or combined with other pests) are major constraints (Lescot and Chabrier, 2016). Infection with nematodes can interfere with the uptake and transport of nutrients and water, which results in slow growth and lodging sensitivity (Risède et al., 2010).

Researches in Côte d'Ivoire has shown that Pratylenchus coffeae and Radopholus similis are the nematodes that cause the most damage to banana. P. coffeae has experienced rapid expansion and longevity of banana plantations in areas where $P$. coffeae species predominate is reduced to less than 5 years (Gnonhouri and Adiko, 2005). So far, the control of nematodes in banana plantations is mainly based on the application of nematicides (Chabrier et al., 2005). However, nematicides are highly toxic and can have a negative impact on the environment and on a human being (Aubertot et al., 2007).

Therefore, the search for other, less polluting and less expensive, control methods is mandatory (Oka, 2001). The use of organic matter composting could contribute to the biological protection of plants against nematodes (Siddiqui, 2004). Lixiviate is extracted from banana rachis. This extract rich in mineral elements and having antimicrobial properties seems to increase the plant resistance to certain diseases (Álvarez et al., 2001). Thus, the effectiveness of lixiviate phytosanitary protection against several pathogenic fungi has been demonstrated (Castaño-Zapata et al., 2007; Mogollón and CastañoZapata, 2010). However, the use of lixiviate against nematodes has been bearly explored. The aim of this work is to determine, on the one hand, the effectiveness of several lixiviate doses on vivoplants plantain growth, and on the other hand to estimate the effect of these doses on the activity of $P$. coffeae.

\section{MATERIAL AND METHODS}

In this study, two banana genotypes belonging to two different ploidy groups were used. The cultivar CORNE 1 of the $\mathrm{AAB}$ genomic group which represents more than 
$80 \%$ of the national production of plantain (Traoré et al., 2009). As for the cultivar PITA 3 , it is a primary hybrid of the AAAB genomic group that is being disseminated in Côte d'Ivoire. The plants (100 per cultivar) are the result of the multiplication on a hulled stock. They were provided by the Centre National de Recherche Agronomique (CNRA) after the weaning and are free from nematode infection.

Lixiviate preparation: Five of dessert banana rachis were cut on the day of harvest diets into small pieces (3$4 \mathrm{~cm}$ thick and 5-10 cm in length) and mixed with $15 \mathrm{~L} \mathrm{of}$ distilled water in a $20 \mathrm{~L}$ barrel. Then the barrel was sealed and kept under ambient laboratory conditions (25 to 27 ${ }^{\circ} \mathrm{C}$ ). The mixture was stirred manually and vigorously for two minutes each day. After 2 months of incubation, the infusion obtained was filtered using a $250 \mu \mathrm{m}$ diameter mesh sieve. The filtrate obtained is the lixiviate. This lixiviate stock solution (lixiviate 100\%) was diluted to 5\% and $25 \%$ in distilled water to obtain respective concentrations of lixiviate $5 \%$ and $25 \%$.

Determination of effective lixiviate dose during the growth phase: The growth phase took place in a greenhouse. The plants were put individually in a polyethylene bag of $20 \mathrm{~cm}$-diam and of $25 \mathrm{~cm}$ in depth, containing sand from the vicinity of the station and the peat taken from Société d'Etude et de Développement de la Culture Bananière de Niéky (Dabou), in (1:1) proportion. This substrate has been sterilized by steam (Jaizme-Vega et al., 2002) and the growth phase lasted a month.

During this time, a batch of 25 banana plants received only distilled water (lix-), and 3 other batches of equivalent number of plants was sprayed respectively with pure (100\% of lixiviate called lix 100 ), $25 \%$ dose of lixiviate (called lix25) and a 5\% dose of lixiviate (called lix5).

The experience was consisting of 8 treatments (4 lixiviate doses by 2 cultivars). At the end of the experiment, five plants per treatment and for each variety were selected for the evaluation of certain agronomic parameters (mass of root system, the collar circumference, pseudostem height, leaf area and a number of leaves).

Greenhouse assessment of the effect of lixiviate on the harmfulness of Pratylenchus coffeae: Plants treated with lixiviate at $25 \%, 5 \%$, and $0 \%$ doses were used for this experiment as $100 \%$ lixiviate dose caused leaf phytotoxicity for plants that received this dose. Sixty plants per cultivar were transferred to another greenhouse. The plants were transplanted into six-liter pots containing a mixture of sand and (1:1) sterilized by steam (Jaizme-Vega et al., 2002). They were kept under natural lighting, then watered as needed. The temperature oscillated from 25 to $30^{\circ} \mathrm{C}$ during experimentation inside the greenhouse.

Inoculum preparation: Isolates of $P$. coffeae used were extracted from roots taken from banana (variety ORISHELE). The root samples were taken from a banana plantation located $10 \mathrm{~km}$ North of Azaguié. This pathotype of Azaguié is characterized by a strong aggressiveness (Konan, 2016). Nematodes were extracted from roots according to the sprinkler method of Seinhorst (1950). The inoculum was made from the nematodes extracted for 48 hours and then adjusted to a concentration of 100 nematodes per ml of water.

Inoculation of plants: The nematodes were inoculated into 5 different holes of $2-3 \mathrm{~cm}$ deep, uniformly distributed in the soil near the stipe using a pipette. Each plant received 500 nematodes i.e. $5 \mathrm{ml}$ of inoculum. For each lixiviate dose (lix-, lix 5\%, and lix 25\%) 10 plants were inoculated (T1) and the other 10 non-inoculated plants served as control plants (T0). This inoculation was done for each of the two cultivars.

The plant-nematode contact period time, lasted 30 days. At the end of this period time, all plants were removed for a second agronomic parameters' evaluation. Those parameters that were evaluated for this experiment were: mass of root system, collar circumference, plant height, leaf area and a number of leaves issued.

For the second experiment, the effect of lixiviate pretreatment on nematodes was also evaluated through the necrosis index and the evolution of the nematode population. For the determination of root necrosis percentage per banana, 5 functional primary roots measuring at least $10 \mathrm{~cm}$ were chosen at random. The roots have been cut longitudinally. The percentage of root cortex showing necrosis was noted for each half root according to the scale of Speijer and De-Waele (1997). The nematode population contained in the roots was evaluated after extracting nematodes by centrifugationflotation technique (Vilardebo and Guérout, 1974).

Statistical analysis: The STATISTICA 7.1 software was used to process the data of this study. ANOVA 2 analysis of variance was performed to see the impact of the factors or their interaction on the analyzed parameters.

The Mann-Whitney $U$ test was used for the statistical significance $(\mathrm{P}<0.05)$ between inoculated plants and uninoculated plants of the same lixiviate dose and from the same cultivar. Nematodes have been transformed into 
decimal logarithm $(\log 10(\mathrm{x}+1))$ and the percentages were transformed into Arcsine ( $x / 100)$ before the statistical analysis.

\section{RESULTS}

Effect of different lixiviate doses on the agronomic parameters of cultivars: The statistical analysis had shown that the lixiviate doses have a significant $(\mathrm{P}<0.05)$ impact on all the agronomic parameters studied (Table
1). This Table shows that all agronomic parameters grew best in treatment $5 \%$ and $25 \%$ lixiviate. In contrast, the $100 \%$ lixiviate dose gave significantly $(\mathrm{P}<0.05)$ lower values compared to the control, for all agronomic parameters. Even phytotoxicity, have been observed on the foliage of almost all plants treated with the $100 \%$ lixiviate dose.

Table 1. Agronomic parameters of vivoplant of PITA 3 and CORNE 1 cultivars according to different lixiviate doses.

\begin{tabular}{|c|c|c|c|c|c|c|}
\hline & $\begin{array}{l}\text { Lixiviate } \\
\text { dose }\end{array}$ & Root Mass (g) & $\begin{array}{c}\text { Number of } \\
\text { leaves issued }\end{array}$ & $\begin{array}{c}\text { Collar } \\
\text { circumference }(\mathrm{cm})\end{array}$ & $\begin{array}{l}\text { Pseudostem } \\
\text { height }(\mathrm{cm})\end{array}$ & $\begin{array}{c}\text { Leaf area } \\
\left(\mathrm{cm}^{2}\right)\end{array}$ \\
\hline \multirow[t]{4}{*}{ CORNE 1} & lix- & $6,8 \pm 0,9$ & $2,8 \pm 0,2$ & $4,08 \pm 0,4$ & $8,1 \pm 1$ & $78 \pm 20,8$ \\
\hline & $\operatorname{lix} 100$ & $2,4 \pm 0,3$ & $0,7 \pm 0,4$ & $2,8 \pm 0,5$ & $4,8 \pm 0,6$ & $24,3 \pm 6,2$ \\
\hline & Lix25 & $25,5 \pm 3,8$ & $3,3 \pm 0,3$ & $4,6 \pm 0,4$ & $13 \pm 2,9$ & $119 \pm 20,6$ \\
\hline & Lix5 & $27,4 \pm 4$ & $3,4 \pm 0,5$ & $4,6 \pm 0,7$ & $12,1 \pm 2,4$ & $122,3 \pm 8,1$ \\
\hline \multicolumn{2}{|c|}{ Average CORNE 1} & $15,5 \pm 11,6 \mathrm{~b}$ & $2,5 \pm 1,9 a$ & $4 \pm 0,9 b$ & $9,5 \pm 3,8 \mathrm{a}$ & $86 \pm 43 b$ \\
\hline \multirow[t]{4}{*}{ PITA 3} & lix- & $10,7 \pm 1,5$ & $3 \pm 0,1$ & $4,5 \pm 0,5$ & $8,3 \pm 1,1$ & $79,5 \pm 15$ \\
\hline & $\operatorname{lix} 100$ & $1,8 \pm 0,3$ & $0,3 \pm 0,2$ & $2,9 \pm 0,1$ & $3,9 \pm 0,3$ & $16,7 \pm 3,4$ \\
\hline & Lix25 & $33,6 \pm 4,2$ & $3,6 \pm 0,3$ & $5,8 \pm 0,5$ & $14,4 \pm 0,7$ & $182,7 \pm 23,8$ \\
\hline & Lix5 & $34,4 \pm 3,1$ & $3,5 \pm 0,3$ & $5,5 \pm 1$ & $14,3 \pm 1,5$ & $174,7 \pm 26,5$ \\
\hline \multicolumn{2}{|c|}{ Average PITA 3} & $20,1 \pm 14,8 \mathrm{a}$ & $2,6 \pm 1,4 \mathrm{a}$ & $4,7 \pm 1,3 \mathrm{a}$ & $10,2 \pm 4,7 \mathrm{a}$ & $113,4 \pm 73 \mathrm{a}$ \\
\hline \multirow{4}{*}{$\begin{array}{l}\text { average of } \\
\text { the lixiviate } \\
\text { doses }\end{array}$} & lix- & $8,8 \pm 2,3 b$ & $3 \pm 0,2 \mathrm{a}$ & $4,3 \pm 0,5 b$ & $8,2 \pm 1 b$ & $78,8 \pm 17,1 \mathrm{~b}$ \\
\hline & $\operatorname{lix} 100$ & $2,1 \pm 0,4 \mathrm{c}$ & $0,5 \pm 0,4 b$ & $2,8 \pm 0,3 c$ & $4,3 \pm 0,7 \mathrm{c}$ & $20,5 \pm 6,2 \mathrm{c}$ \\
\hline & Lix25 & $29,6 \pm 5,7 \mathrm{a}$ & $3,5 \pm 0,4 a$ & $5,2 \pm 0,7 a$ & $13,7 \pm 2,1 \mathrm{a}$ & $150,9 \pm 39,6 a$ \\
\hline & Lix5 & $30,9 \pm 5,1 \mathrm{a}$ & $3,4 \pm 0,4 \mathrm{a}$ & $5 \pm 0,9 \mathrm{a}$ & $13,3 \pm 2,1 \mathrm{a}$ & $148,5 \pm 33,2 \mathrm{a}$ \\
\hline \multicolumn{2}{|c|}{ Effect of the cultivar } & 0,000009 & 0,534878 & 0,001345 & 0,146979 & 0,000023 \\
\hline \multicolumn{2}{|c|}{ Effect of the lixiviate doses } & 0,000000 & 0,000000 & 0,000000 & 0,000000 & 0,000000 \\
\hline \multicolumn{2}{|l|}{ Interaction } & 0,006294 & 0,119522 & 0,181036 & 0,136356 & 0,000063 \\
\hline
\end{tabular}

In the same column, the averages affected with different letters indicate significant differences between treatments according to Fischer's LSD test $(\mathrm{P}=0,05)$

lix - : control sample ; lix100 : pure lixiviate ; lix25 : $25 \%$ lixiviate dose ; lix5 : 5 \% lixiviate dose

The cultivar type has also an impact on the agronomic parameters (Table 1). PITA 3 cultivar gave significantly higher values $(\mathrm{P}<0.05)$ than CORNE 1 cultivar for the root mass, the collar circumference, and the leaf area. No significant difference $(\mathrm{P}>0.05)$ was observed between PITA 3 and CORNE 1 cultivars for the number of leaves and the pseudo stem height.

For all the parameters studied, the interaction between cultivars and the lixiviate dose was only significant $(\mathrm{P}<$ 0.05 ) for the root mass and the leaf area (Table 1).

\section{Effect of lixiviate on the nuisance of $P$. coffeae}

Evolution of the nematode population: The second experiment has shown that, except for the $25 \%$ lixiviate dose in the cultivar PITA 3 where the number of nematodes in the root is less than the number of inoculated nematodes (237 vs. 500 individuals), the number of nematodes in the root is upper than the number of nematodes at the starting inoculum whatever the cultivar (Figure 1). In the cultivar PITA 3, this number varies from 1057 to 4507 nematodes whereas it is 1560 to 7544 nematodes in the cultivar CORNE 1 .

Healthcare of the roots: For the two cultivars (PITA 3 and CORNE 1) pretreated with lixiviate doses (lix-, and lix5), the percentage of necrosis on inoculated plants was significantly higher $(\mathrm{P}<0.05)$ than that related to uninoculated plants. On the other hand, for plants pretreated with the $25 \%$ lixiviate dose, then inoculated with the nematode and those not inoculated, the average percentage of root necrosis was not significantly different $(P>0.05)$ regardless of the cultivar (Table 2). 


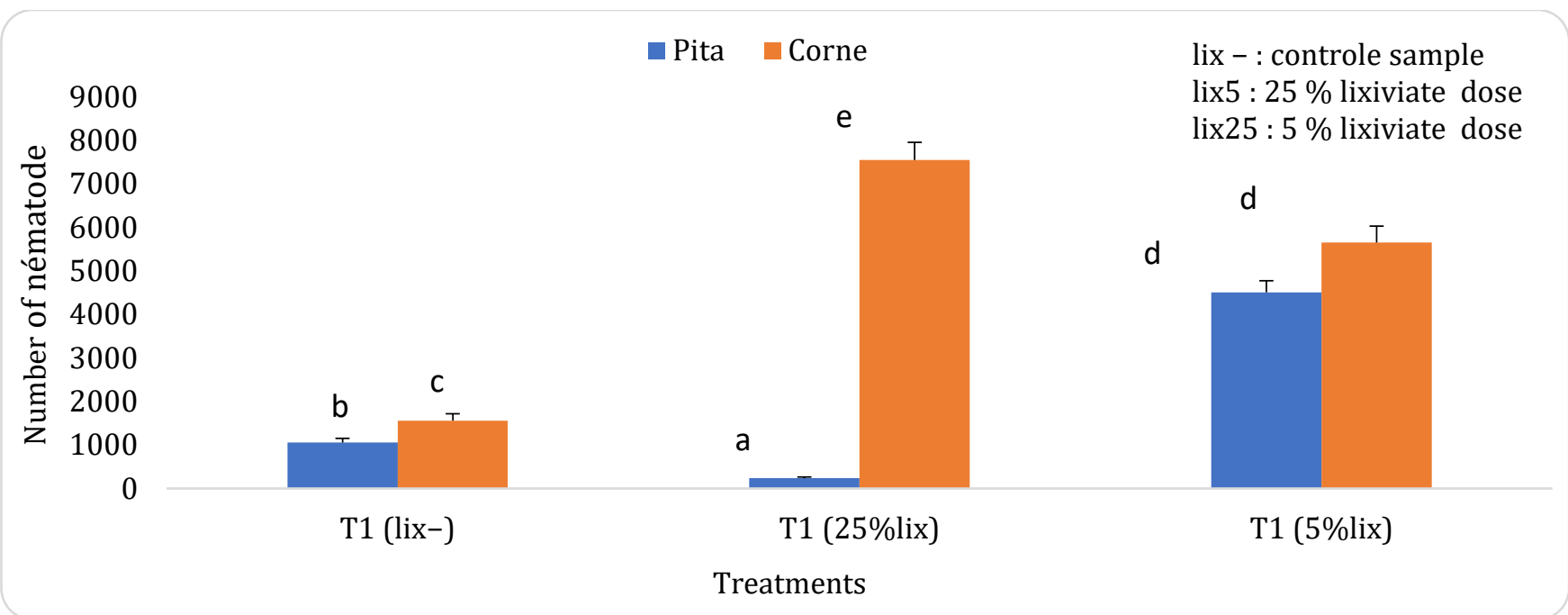

Figure 1. average number of nematodes according to different treatment (lixiviate concentration) for PITA 3 and CORNE 1cultivars.

For a given concentration of lixsiviate, the histograms of same letters are not significantly different (Fisher's LSD test, $\mathrm{p}$ $<0.05)$.

Table 2. Percentage of root necrosis caused by Pratylenchus coffeae on plants of PITA 3 and CORNE 1 cultivars pretreated with different lixiviate doses.

\begin{tabular}{|c|c|c|c|}
\hline & \multirow{3}{*}{ Treatment } & \multicolumn{2}{|c|}{ Root necrosis \% } \\
\hline & & \multicolumn{2}{|c|}{ Cultivars } \\
\hline & & PITA 3 & CORNE 1 \\
\hline \multirow[t]{3}{*}{ lix - } & T0 & $8,2 \pm 1,8 \mathrm{a}$ & $9,45 \pm 2,2 \mathrm{a}$ \\
\hline & $\mathrm{T} 1$ & $22,6 \pm 4,5 b$ & $39,4 \pm 6,8 b$ \\
\hline & $\mathrm{P}$ & 0,000157 & 0,000157 \\
\hline \multirow[t]{3}{*}{ Lix25 } & T0 & $9,4 \pm 2,4 \mathrm{a}$ & $14,1 \pm 3,8 \mathrm{a}$ \\
\hline & $\mathrm{T} 1$ & $9,9 \pm 3 a$ & $14,65 \pm 3,2 \mathrm{a}$ \\
\hline & $\mathrm{P}$ & 0,762369 & 0,791337 \\
\hline \multirow[t]{3}{*}{$\operatorname{lix} 5$} & T0 & $10 \pm 2,6 \mathrm{a}$ & $12,3 \pm 1,7 \mathrm{a}$ \\
\hline & $\mathrm{T} 1$ & $13,8 \pm 3,3 b$ & $20,4 \pm 3,3 \mathrm{~b}$ \\
\hline & $P$ & 0,031210 & 0,000183 \\
\hline
\end{tabular}

In the same column, the averages affected with different letters indicate significant differences between treatments according to Mann-Whitney's U test. $(\mathrm{P}=0,05)$.

lix- : control sample without lixiviate ; lix25 : $25 \%$ lixiviate dose; lix5 : $5 \%$ lixiviate dose.

Evaluation of growth parameter: Whatever the cultivar without lixiviate dose (lix-): all the agronomic parameters (root mass, number of leaves, collar circumference, pseudostem height, and leaf area) of plants infested with P. coffeae were significantly lower $(\mathrm{P}<0.05)$ than those of the control plants samples (Table 3). Depending on the cultivar, the root mass decreased by more than $70 \%$, the number of leaves and the collar circumference suffered further losses by $80 \%$ and the height of the pseudostem falls by at least $12 \%$. For the surface foliar, the decrease observed was approximately $75 \%$.

For $5 \%$ lixiviate dose, the root mass of plants infested with $P$. coffeae decreased by $13 \%$ compared to control plant samples in both cultivars. All aerial parameters (collar circumference, pseudo-trunk height, leaf area and a number of leaves) of the inoculated plants are not significantly different $(P>0.05)$ from uninoculated plants in PITA 3 cultivar. Inoculated plants of CORNE 1 cultivars have a leaf area significantly lower $(P<0.05)$ than uninoculated plants of the same cultivar (Table 3 ). 
Table 3. Agronomic Parameters of plants of PITA 3 and CORNE 1 cultivars treated with different lixiviate doses and incolated with Pratylenchus coffeae.

\begin{tabular}{|c|c|c|c|c|c|c|c|c|c|c|c|}
\hline & $\begin{array}{l}\text { Agronomic } \\
\text { Parameters }\end{array}$ & \multicolumn{2}{|c|}{ Roots mass (g) } & \multicolumn{2}{|c|}{ Number of leaves } & \multicolumn{2}{|c|}{ Collar circumference $(\mathrm{cm})$} & \multicolumn{2}{|c|}{ Pseudo stem height (cm) } & \multicolumn{2}{|c|}{ Leaf area $\left(\mathrm{cm}^{2}\right)$} \\
\hline & \multicolumn{11}{|c|}{ Cultivars } \\
\hline & Treatments & PITA 3 & CORNE 1 & PITA 3 & CORNE 1 & PITA 3 & CORNE 1 & PITA 3 & CORNE 1 & PITA 3 & CORNE 1 \\
\hline \multirow[t]{3}{*}{ lix - } & T0 & $20,8 \pm 2,4 a$ & $16,1 \pm 2,4 \mathrm{a}$ & $4,9 \pm 0,6 \mathrm{a}$ & $4,3 \pm 0,5 \mathrm{a}$ & $5,7 \pm 1 \mathrm{a}$ & $4,7 \pm 0,8 \mathrm{a}$ & $15,7 \pm 3,2 \mathrm{a}$ & $13,9 \pm 1,5 \mathrm{a}$ & $182,6 \pm 16 \mathrm{a}$ & $122,5 \pm 12,7 \mathrm{a}$ \\
\hline & $\mathrm{T} 1$ & $14,7 \pm 1,8 b$ & $9,5 \pm 1,9 b$ & $3,9 \pm 0,6 b$ & $3,1 \pm 0,4 b$ & $4,7 \pm 0,9 b$ & $3,4 \pm 0,7 \mathrm{~b}$ & $12,8 \pm 2,3 b$ & $9,9 \pm 1,8 b$ & $129,3 \pm 21 b$ & $93 \pm 11 b$ \\
\hline & $\mathrm{P}$ & 0,000183 & 0,000285 & 0,005159 & 0,000381 & 0,049369 & 0,001990 & 0,034294 & 0,000881 & 0,000212 & 0,000381 \\
\hline \multirow[t]{3}{*}{$\operatorname{lix} 25$} & T0 & $49 \pm 5,6 a$ & $38,3 \pm 5 a$ & $6 \pm 0,4 a$ & $5,53 \pm 0,5 a$ & $6,4 \pm 1,2 \mathrm{a}$ & $6,1 \pm 1,4 \mathrm{a}$ & $23,2 \pm 3,4 \mathrm{a}$ & $19,6 \pm 1,9 \mathrm{a}$ & $369,8 \pm 23 a$ & $314,4 \pm 35,4 \mathrm{a}$ \\
\hline & $\mathrm{T} 1$ & $47,1 \pm 7,4 \mathrm{a}$ & $36,9 \pm 4 a$ & $5,8 \pm 0,5 a$ & $5,3 \pm 0,5 a$ & $6,2 \pm 1,2 \mathrm{a}$ & $6 \pm 1,3 \mathrm{a}$ & $23,1 \pm 3,4 \mathrm{a}$ & $19 \pm 2,5 a$ & $356 \pm 41,4 a$ & $303,8 \pm 40,1 \mathrm{a}$ \\
\hline & $P$ & 0,496292 & 0,596702 & 0,273037 & 0,325752 & 0,596702 & 0,820596 & 0,850107 & 0,570751 & 0,256840 & 0,650148 \\
\hline \multirow[t]{3}{*}{$\operatorname{lix} 5$} & T0 & $50,2 \pm 6 a$ & $37,1 \pm 8,7 \mathrm{a}$ & $5,8 \pm 0,6 a$ & $5,4 \pm 0,5 \mathrm{a}$ & $6 \pm 0,5 a$ & $5,8 \pm 0,8 \mathrm{a}$ & $20,2 \pm 3,4 \mathrm{a}$ & $19,31 \pm 3,1 a$ & $305 \pm 42,2 \mathrm{a}$ & $293,6 \pm 24,6 a$ \\
\hline & $\mathrm{T} 1$ & $43,2 \pm 7,5 b$ & $30,1 \pm 5,7 b$ & $5,6 \pm 0,6 a$ & $5,3 \pm 0,5 a$ & $5,5 \pm 0,8 \mathrm{a}$ & $5,4 \pm 1 \mathrm{a}$ & $19,3 \pm 2,8 \mathrm{a}$ & $18,98 \pm 2,3 a$ & $292 \pm 34,2 \mathrm{a}$ & $242,7 \pm 38 b$ \\
\hline & $\mathrm{P}$ & 0,041251 & 0,069643 & 0,520523 & 0,449692 & 0,140466 & 0,212295 & 0,449692 & 0,879829 & 0,650148 & 0,006502 \\
\hline
\end{tabular}

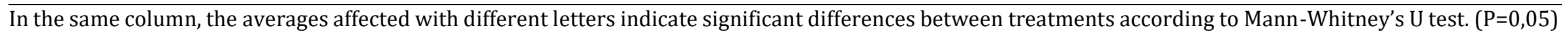
lix-: control sample without lixiviate ; lix25 : $25 \%$ lixiviate dose; lix5 : $5 \%$ lixiviate dose.

For 25\% lixiviate dose, the agronomic parameters were not influenced by nematode infestation, of each cultivar. Indeed, a reversed trend was observed compared to the two previous observations. No major difference $(\mathrm{P}>0.05)$ was observed between plants inoculated with $P$. coffeae (T1) and the control sample plants (T0) (Table 3).

\section{DISCUSSION}

The results showed that 5\% and 25\% lixiviate doses were more effective on the agronomic parameters than the $100 \%$ lixiviate dose. Such comments have been made by Escobar and Castano (2005) who obtained a higher banana weight than that of the control sample after applying a $0.5 \%$ lixiviate dose. The lixiviate dose application (5\% and $25 \%$ ) had a more positive effect on the growth of vivoplants form PITA 3 cultivars. These results are in agreement with those of Thiemele et al.
(2015) who shown the better behavior of PITA 3 cultivar compared to FHIA 21, ORISHELE and CORNE 1 cultivars after application of cytokinin. On the other hand, for $100 \%$ lixiviate dose, phytotoxicity effects were observed and confirmed by the work of Álvarez et al. (2001) who showed that, starting from the $50 \%$ dose, the application of lixiviate causes phytotoxicity phenomena on the foliage.

High variability of nematode was observed at the roots of the treated plants. In fact, the amount of nematode was higher, at the roots of both cultivars treated with $5 \%$ lixiviate and those of CORNE 1 cultivar treated with $25 \%$ lixiviate, compared to other lixiviate dosage. it could be explained by the important root mass caused by $5 \%$ and $25 \%$ lixiviate dosage.

These results are similar to those of Yeates (1987) who noticed that an increase in the root system led to an increase of phytoparasitic nematodes and vice versa. Presence of $P$. coffeae ha been higher in CORNE 1 cultivar, which is more responsive to this nematode than PITA 3 cultivar. These results are in agreement with those of Speijer and Bosch (1996) who showed that traditional varieties seemed more responsive to Pratylenchus spp. compared to newly introduced varieties in Tanzania. The nearly absence of $P$. coffeae at the root plant of PITA 3 cultivar treated with $25 \%$ lixiviate dose could show the existence of resilience factors. Indeed, after application of the lixiviate dosage, cultivar PITA 3 could show a low attractiveness or a repulsive action as shown by Caswell et al. (1991) in their study of the changes in root exudates perceived by nematodes in the case of coffee's root plant, resilient to $P$. coffeae. 
Other authors have mentioned an accumulation of phenolic material (Hahlbrock and Scheel, 1989) following lixiviate treatment. The role of phenolic compounds as substances that narrow the spread and the progress of nematodes in banana root tissues has been described by Valette (1996). Banana plants that have not been treated with lixiviate and inoculated with nematodes were strongly necrotic, reducing the functional root area. Indeed, it has been shown that the direct damage of the nematode is more important for the roots system of low density (Tabarant, 2011).

The decrease of all growth parameters observed is the consequence of the impact of nematodes on the root system. This result is supported by Mukasa et al. (2006), who observed a $40 \%$ decrease in aerial biomass on banana plants after an attack of nematodes.

Pretreatment of the both plant cultivars with the 5\% lixiviate dose did not prevent health status (percentages of necrosis and dead roots) and root mass from being affected by the nematode. However, a correction of the underground damages has been observed at the aerial level in the PITA 3 cultivar as the whole aerial part (leaves, collar, pseudo stem and leaf area) was not affected.

On the other hand, in the CORNE 1 cultivar, the application of $5 \%$ lixiviate dose does not prevent underground damages from affecting the leaf area. These results are similar to those of Álvarez et al. (2001) who showed that lixiviate prepared from plantain led to resilience to certain diseases. The percentage of necrosis and dead roots are similar for banana inoculated and not inoculated in both cultivars after applying a $25 \%$ lixiviate dose. For plants of the CORNE 1 cultivar with a high nematode concentration, lixiviate at this dose had a very positive effect on plant tolerance to nematode attack. Such comments were also made by Tixier et al. (2006) who claimed that this tolerance could be due to the increase in root system which was a strategy for controlling nematodes.

Other authors, such as Mogollón and Castaño-Zapata (2010), have shown that the lixiviate produced from the composting of banana's scape is rich in nutrients and substances that can influence microorganism by preventing from the tissue lesions expansion. The health status of the roots and the growth of the PITA 3 plants treated at $25 \%$ dose are not affected by inoculation of the nematode. That could be due to, as has mentioned Villain (2000), the resilience mechanism put in place by these plants to prevent the parasitic activity of the nematode.

\section{CONCLUSION}

$5 \%$ and $25 \%$ lixiviate doses gave better agronomic parameters evaluated on vivoplants, while the dosage at $100 \%$ resulted in phytotoxicity. The application of doses at $5 \%$ and $25 \%$ allowed an optimum development of PITA 3 cultivar. The application of $5 \%$ lixiviate dose allows only plants from PITA 3 cultivars to tolerate underground damages, while lixiviate dosed at $25 \%$ allow the CORNE 1 cultivar to tolerate nematodes. That same dose in PITA 3 cultivar, appeared as a way of controlling Pratylenchus coffeae because it reduces the nematode concentration, thus reducing the damages caused by those ones. From these results, we recommend that further studies should be conducted to assess the stability of lixiviate compounds in the soil and promote lixiviate as a nonpolluting phytosanitary control way in banana plantations against $P$. coffea.

\section{REFERENCES}

Álvarez, E., C. Grajales, J. Villegas and J. Loke. 2001. Control del mildeo polvoso (Sphaerotheca pannosa var. rosae) en rosa (Rosa sp.), usando un lixiviado de compost del raquis de plátano (Musa AAB). Revista Asocolflores, 62: 41-47.

Aubertot, J.-N., J. M. Barbier, A. Carpentier, J.-N. Gril, L. Guichard, P. Lucas, S. Savary and M. Voltz. 2007. Pesticides, agriculture et environnement. Réduire l'utilisation des pesticides et en limiter les impacts environnementaux. Expertise scientifique collective Inra-Cemagref INRA et Cemagref, France. pp. 64.

Castaño-Zapata, J., R. B. Gutiérrez and Z. L. Posada. 2007. Efecto Inhibitorio in vitro de lixiviados del raquis de plátano sobre Botryotinia fuckeliana de Bary (Whetzel), causante del Moho gris en flores. Fitopatología Colombiana, 31: 19-22.

Caswell, E. P., C. Tang, J. D. Frank and W. Apt. 1991. The influence of root exudates of Chloris gayana and Tagetes patula on Rotylenchulus reniformis. Revue Nematol, 14: 581-87.

Chabrier, C., J. Hubervic and P. Quénéhervé. 2005. Evaluation de l'efficacité de deux formulations d'oxamyl contre les nématodes et charançons des bananiers à la martinique. Nematropica, 35: 11-22.

Escobar, V. J. H. and Z. Castano. 2005. Traitement des maladies causées par les Mycosphaerella spp. par application d'acides fulviques. Info Musa, 14: 15-17.

Gnonhouri, G. P. and A. Adiko. 2005. Résultats de prospections nématologiques réalisées en culture 
de banane de dessert en Côte d'Ivoire CORUSNEMATOLOGIE, rapport de la première étape. pp. 4-7.

Hahlbrock, K. and D. Scheel. 1989. Physiology and molecular biology of phenylpropanoid metabolism. Annual Review of Plant Physiology and Plant Molecular Biology, 40: 347-69.

Jaizme-Vega, M. C., M. Esquivel-Delamo, P. TenouryDomínguez and A. S. Rodríguez-Romero. 2002. Effet de la mycorhization sur le développement de deux cultivars de bananier issus de micropropagation. Infomusa, 11: 25-28.

Konan, E. 2016. Diversité pathotype de Pratylenchus coffeae en Côte d'Ivoire, Université Lorougnon Guédé.

Lescot, T. and C. Chabrier. 2016. Amélioration de la culture de la banane en Haiti Projet de sécurité alimentaire SECAL-OUEST. Rapport de mission. pp. 39.

Mogollón, A. and J. Castaño-Zapata. 2010. Evaluación in vitro de lixiviados del raquis de plátano sobre Paracercospora fijiensis (Morelet) Deighton. Agronomía, 18: 17-23.

Mukasa, H. H., D. Ocan, D. De Waele, P. R. Rubaihayo and G. Blomme. 2006. Effect of a multispecies nematode population on the root, corm, and shoot growth of East African Musa genotypes. Biology and Fertility of Soils, 43: 229-35.

Oka, Y. 2001. Nematicidal activity of essential oil components against the root-knot nematode Meloidogyne javanica. Nematology, 3: 159-64.

Risède, J.-M., C. Chabrier, M. Dorel, T. Dambas, R. Achard and P. Quénéhervé. 2010. Protection intégrée contre les nématodes du bananier: enseignements tirés de l'étude de cas des Antilles françaises françaises Étude de Cas sur la Banane.

Seinhorst, J. W. 1950. De betekenis van de toestand van de grond voor het optreden van aantasting door het stengelaaltje (Ditylenchus dipsaci (Kühn) Filipjev). Tijdschrift Over Plantenziekten, 56: 289-348.

Siddiqui, Z. 2004. Effects of plant growth promoting bacteria and composed organic fertilizers on the reproduction of Meloidogyne incognita and tomato growth. Bioresource Technology, 95: 223-27.

Speijer, P. R. and C. H. Bosch. 1996. Susceptibility of Musa cultivars to nematodes in Kagera Region, Tanzania. Fruits, 4: 217-22.

Speijer, P. R. and D. De-Waele. 1997. Evaluation du matériel génétique de Musa pour la résistance aux nématodes Réseau international pour l'amélioration de la banane et de la banane plantain. INIBAP. Montpellier, France. pp. 47.

Tabarant, P. 2011. Effets d'apport de matières organiques sur le contrôle biologique des nématodes parasites du bananier en Guadeloupe, Paris Tech.

Thiemele, D. E. F., A. E. Issali, S. Traore, K. M. Kouassi, N. Aby, P. G. Gnonhouri, J. K. Kobenan, T. N. Yao, A. Adiko and A. N. Zakra. 2015. Macropropagation of plantain (Musa spp.) cultivars Pita 3, Fhia 21, Orishele and Corne 1: Effect of benzylaminopurine (bap) concentration. Journal of Plant Development, 22: 31-39.

Tixier, P., J. M. Risède, M. Dorel and E. Malézieux. 2006. Modelling population dynamics of banana plantparasitic nematodes: A contribution to the design of sustainable cropping systems. Ecological Modelling, 198: 321-31.

Traoré, S., K. Kobenan, K. S. Kouassi and G. P. Gnonhouri. 2009. Systèmes de culture du bananier plantain et méthodes de lutte contre les parasites et ravageurs en milieu paysan en Côte d'Ivoire. Journal of Applied Biosciences, 19: 1094-101.

Valette, C. 1996. Etude de la variabilité des interactions bananier-nématode: approche des facteurs de la résistance du bananier à Radopholus similis, Université de Paris.

Vilardebo, A. and A. Guérout. 1974. Technique d'extraction de Radopholus similis des racines de bananiers. In, Méthodes d'essais d'efficacité" pratique de nématicides étudiés sur Radopholus similis Cobb en bananeraies. Soc. Franç: Phytiatire et phytopharmacie.

Villain, L. 2000. Caractérisation et bioécologie du complexe parasitaire du genre\# Pratylenchus (Nemata: Pratylenchidae) présent sur caféiers (Coffea spp.) au Guatemala, Ecole Nationale Supérieure Agronomique De Rennes.

Yeates, G. W. 1987. How Plants Affect Nematodes Advances in Ecological Research. Elsevier. pp. 61113. 
Publisher's note: EScience Press remains neutral with regard to jurisdictional claims in published maps and institutional affiliations.

(c) (i)

Open Access This article is licensed under a Creative Commons Attribution 4.0 International License, which permits use, sharing, adaptation, distribution and reproduction in any medium or format, as long as you give appropriate credit to the original author(s) and the source, provide a link to the Creative Commons license and indicate if changes were made. The images or other third-party material in this article are included in the article's Creative Commons license, unless indicated otherwise in a credit line to the material. If material is not included in the article's Creative Commons license and your intended use is not permitted by statutory regulation or exceeds the permitted use, you will need to obtain permission directly from the copyright holder. To view a copy of this license, visit http://creativecommons.org/licenses/by/4.0/.

(C) The Author(s) 2018. 